\section{Effects of Different Fumigants on the Replanted Soil Environment and Growth of Malus hupehensis Rehd. Seedlings}

\author{
Ran Chen, Weitao Jiang, Haiyan Wang, and Fengbing Pan \\ State Key Laboratory of Crop Biology/College of Horticultural Science and \\ Engineering, Shandong Agricultural University, Tai'an 271018, Shandong, \\ China
}

\section{Hai Fan}

College of Chemistry and Material Science, Shandong Agricultural University, Tai'an 271018, Shandong, China

Xuesen Chen, Xiang Shen, Chengmiao Yin, and Zhiquan Mao State Key Laboratory of Crop Biology/College of Horticultural Science and Engineering, Shandong Agricultural University, Tai'an 271018, Shandong, China

Additional index words. apple replant disease, ARD, dazomet, Fusarium oxysporum, metham sodium, plant morphological properties, soil physicochemical properties

\begin{abstract}
Apple replant disease (ARD) has been reported in all major fruit-growing regions of the world and is often caused by biotic factors (pathogen fungi) and abiotic factors (phenolic compounds). Soil chemical fumigation can kill soil pathogenic fungi; however, the traditionally used fumigant methyl bromide has been banned because of its ozone-depleting effects. There is thus a need to identify greener fumigant candidates. We characterized the effects of different fumigants on the replanted soil environment and the growth characteristics of Malus hupehensis Rehd. seedlings. All five experimental treatments [treatment 1 (T1), metham-sodium; treatment 2 (T2), dazomet; treatment 3 (T3), calcium cyanamide; treatment 4 (T4), 1,3-dichloropropene; and treatment 5 (T5), methyl bromide] promoted significantly the biomass, root growth, and root respiration rate of $M$. hupehensis seedlings and the ammonium nitrogen $\left(\mathrm{NH}_{4}{ }^{+}-\mathrm{N}\right)$ and nitrate nitrogen $\left(\mathrm{NO}_{3}{ }^{-}-\mathrm{N}\right)$ contents of replanted soil. Metham sodium (T1) and dazomet (T2) had stronger effects compared with 1,3dichloropropene (T4) and calcium cyanamide (T3). At 172 days after T1, the height, root length, and root respiration rate of Malus hupehensis Rehd. seedlings, and the $\mathrm{NH}_{4}{ }^{+} \mathrm{N}$ and $\mathrm{NO}_{3}^{-}-\mathrm{N}$ contents of replanted soil increased by $91.64 \%, 97.67 \%, 69.78 \%, 81.98 \%$, and $\mathbf{2 7 . 4 4 \%}$, respectively, compared with the control. Thus, dazomet and metham sodium were determined to be the optimal fumigants for use in practical applications.
\end{abstract}

Apple replant disease (ARD) is an inevitable problem associated with the development of the modern apple industry (Sheng

\footnotetext{
Received for publication 22 Dec. 2020. Accepted for publication 27 Jan. 2021.

Published online 5 March 2021

The research was supported by the earmarked fund for the National Modern Agro-industry Technology Research System of China (CARS-27), the National Natural Science Foundation of China (32072510), the Shandong Agricultural Major Applied Technology Innovation Project (SD2019ZZ008); the Taishan Scholar Funded Project (NO.ts20190923); the Qingchuang Science and Technology Support Project of Shandong Colleges and Universities (2019KJF020); the Natural Science Foundation of Shandong Province (ZR2020MC131); and the Fruit Innovation Team in Shandong Province, China (SDAIT-06-07).

Z.M. is the corresponding author. E-mail: mzhiquan@ sdau.edu.cn.

This is an open access article distributed under the CC BY-NC-ND license (https://creativecommons. org/licenses/by-nc-nd/4.0/).
}

et al., 2020; Wang et al., 2014) that seriously restricts the development of China's apple industry (Sheng et al., 2020). Several studies have shown that the increase of pathogenic microorganisms in soil under replanted conditions is the main cause of ARD (Yim et al., 2013). Therefore, controlling soil pathogenic microorganisms is key to preventing and controlling ARD. Current methods used to control ARD include soil fumigation, the application of large amounts of organic materials, and biological control (Nicola et al., 2017). Because organic material resources are often lacking and the effect of biological control is not substantial, soil fumigation has generally been the most effective method for preventing and controlling ARD (Ren et al., 2018).

Methyl bromide, a chemical fumigant that is also an effective disinfectant, has been banned globally because of its ozonedepleting effects (Hoffmann et al., 2020). Since then, several chemical fumigants have appeared on the market to replace methyl bromide, such as benzamide, sodium methylamine, and 1,3-dichloropropene (Yan et al., 2017). Metham sodium, a type of methylamine derivative that can decompose in moist soil to produce methyl isothiocyanate; block the division of biological cells as well as DNA, RNA, and protein synthesis; and has toxic effects (Bangarwa et al., 2009), is commonly used to control soil-borne diseases in fields of vegetables, peanuts, tobacco, and other crops (Frank et al., 1986). Pinkerton et al. (2000) found that metham sodium reduced significantly the incidence of Phytophthora infestans and verticillium wilt pathogens in eggplant. In addition, soil fumigation using metham sodium could also reduce root swelling and improve plant health (Hwang et al., 2017), control effectively corky ringspot of potato tuber and potato wilt disease caused by replanting, and improve tuber quality (Yellareddygari and Gudmestad, 2018). Dazomet, a broad-spectrum soil fungicide, is widely used to prevent and control soil-borne diseases such as ginger stem rot, Phytophthora capsica, and tomato root-end nematode, and protects crops from a series of pathogenic bacteria through the release of methyl isothiocyanate (Mao et al., 2014; Ślusarski and Pietr, 2009). Meng et al. (2019) found that dazomet fumigation affected primarily the characteristics of fungi, and could reduce the number of Fusarium oxysporum - a pathogenic bacteriumand improve the yield of watermelon. Chen et al. (2019) found that dazomet fumigation reduced significantly the number of bacteria and fungi in replanted soil and controlled chrysanthemum fusarium wilt effectively. 1,3-Dichloropropene, a soil fumigant and nematicide, is used primarily for strawberries, sweetpotatoes, melons, flowers, and other crops before planting, soil fumigation, and processing; it has been shown to be effective in controlling worms, plant pathogenic bacteria, and weeds (Qiao et al., 2010). Qiao et al. (2012) found that tomato root-knot nematode disease was reduced significantly, and the growth of tomatoes was promoted, after fumigating soil with 1,3-dichloropropene. Calcium cyanamide is an alkaline nitrogen fertilizer with insecticidal and herbicidal effects. Calcium cyanamide fumigation can optimize the replanted soil environment, improve disease resistance and yield, and promote the growth of cucumber (Bletsos, 2010). Fan et al. (2016) found that calcium cyanamide fumigation could alleviate strawberry replant disease effectively.

To date, most studies have focused on the control of nematodes and weeds by fumigants, especially in cash crops such as vegetables and flowers (Ibekwe, 2004). In contrast, few studies have focused on the prevention and reduction of ARD and compared the efficacy of different fumigants. In our study, apple rootstock Malus hupehensis seedlings were used in pot experiments to examine the effects of five fumigants on the biological characteristics of the soil microbial environment and $M$. hupehensis seedlings. In general, the goal of this study was to 
determine the most suitable fumigant for ARD control and to provide guiding information to aid in the selection of appropriate fumigants for treating soil for apple tree replanting.

\section{Materials and Methods}

\section{Experimental materials and treatments}

The experiment was conducted in the College of Horticulture Science and Engineering, Shandong Agricultural University, National Apple Engineering Technology Research Center in 2019 (lat. $36.16^{\circ} \mathrm{N}$, long. $\left.117.15^{\circ} \mathrm{E}\right)$. The soil was obtained from a $34-$ year-old apple orchard at Songjiezhuang village (lat. $36.09^{\circ} \mathrm{N}$, long. $117.04^{\circ} \mathrm{E}$ ) in Tai' an City, Shandong. The root stock was Malus micromalus Makino, and test soil was taken randomly from a 10 - to $40-\mathrm{cm}$ depth after removing the topsoil. Multipoint random sampling was used to sample the soil, which was then mixed evenly and air-dried before use. The soil type was brown loam, and its basic physical and chemical properties are summarized in Table 1. The collected soil was treated by five fumigants (Table 2).

Malus hupehensis Rehd. seedlings were used in experiments. The seeds of $M$. hupehensis Rehd. were stratified at $4{ }^{\circ} \mathrm{C}$ for $\approx 40 \mathrm{~d}$. After the seeds became white, they were seeded in the seedling tray in Mar. 2019.

On 17 Apr. 2019, fumigants and soil at the recommended dosage were mixed and sealed for $15 \mathrm{~d}$ to fumigate the soil (Table 3 ). The plastic film was then opened so that the treated soil could be air-dried for $7 \mathrm{~d}(\mathrm{Li}$ et al., 2016), after which the soil was turned regularly to remove the residual fumigant thoroughly. These experiments were conducted under natural conditions. On 9 May 2019 , the seedlings grew five true leaves, and seedlings showing the same growth trend were transplanted to different treatments of clay tile pots (upper inner diameter, $25 \mathrm{~cm}$; lower inner diameter, $17 \mathrm{~cm}$; height, $18 \mathrm{~cm}$ ), with $7 \mathrm{~kg}$ of soil in each basin. Thirty pots were used for each treatment, and two seedlings were planted in each pot for unified fertilizer and water management. Soil samples were collected and measured at $0 \mathrm{~d}$ (the day when the seedlings were exposed to fumigant), $9 \mathrm{~d}$ ( $2 \mathrm{~d}$ after seedlings were planted), $52 \mathrm{~d}$ (45 d after seedlings were planted), $112 \mathrm{~d}$ (105 d after seedlings were planted), and $172 \mathrm{~d}$ (165 d after seedlings were planted) after fumigation. Three pots were selected randomly for each treatment for use as three replicates. During sampling, the soil was removed around the basin and the surface layer, sifted through a 2-mm sieve, and placed into three sealed bags. One bag was stored in a refrigerator at $4{ }^{\circ} \mathrm{C}$ to measure the quantity of microbes and soil nutrient
$\mathrm{NO}_{3}{ }^{-}-\mathrm{N}$ and $\mathrm{NH}_{4}{ }^{+}-\mathrm{N}$ contents. Another bag was placed quickly into liquid nitrogen and stored at $-80^{\circ} \mathrm{C}$ for DNA extraction and realtime fluorescence quantitative polymerase chain reaction (PCR) analysis. The last bag was naturally air-dried to determine soil enzyme activity. At the same time, three seedlings of each treated M. hupehensis Rehd. were collected at $52 \mathrm{~d}, 112 \mathrm{~d}$, and $172 \mathrm{~d}$ after fumigation. After being washed, samples were subjected to root scanning, and biomass and root respiration rate measurements were taken.

\section{$\mathrm{NO}_{3}{ }^{-}-\mathrm{N}$ and $\mathrm{NH}_{4}{ }^{+}-\mathrm{N}$ contents in soil}

Samples were taken at $52 \mathrm{~d}(45 \mathrm{~d}$ after seedlings were planted), $112 \mathrm{~d}$ (105 d after seedlings were planted), and $172 \mathrm{~d}$ (165 d after seedlings were planted) after fumigation. At each sampling event, rhizosphere soil samples of three M. hupehensis Rehd. seedlings were collected from each treatment, placed immediately into zippered bags, and frozen at $-20{ }^{\circ} \mathrm{C}$. After leaching $6 \mathrm{~g}$ of soil with $50 \mathrm{~mL}$ potassium chloride $\left(1 \mathrm{~mol} \cdot \mathrm{L}^{-1}\right)$ solution, the contents of $\mathrm{NO}_{3}{ }^{-}-\mathrm{N}^{-}$and $\mathrm{NH}_{4}{ }^{+}-\mathrm{N}$ in the soil were determined using an AA3 automatic flow analyzer (Xue et al., 2017).

\section{Soil enzyme activity}

Soil urease activity. Soil urease activity was determined by conducting a colorimetric assay using sodium phenate-sodium hypochlorite (Du et al., 2017). First, 5-g, air-dried soil samples were weighed in a $50-\mathrm{mL}$ triangulated flask, and $1 \mathrm{~mL}$ toluene was added, followed by shaking until the contents were mixed evenly. After $15 \mathrm{~min}, 10 \mathrm{~mL}$ of $10 \%$ urea solution and citrate buffer solution were added, followed by shaking and incubation at $37^{\circ} \mathrm{C}$ for $24 \mathrm{~h}$. After culture, the filtrate was filtered, and $1 \mathrm{~mL}$ of filtrate was added to a $50-\mathrm{mL}$ volumetric flask. Next, $4 \mathrm{~mL}$ sodium phenol solution and $3 \mathrm{~mL}$ sodium hypochlorite solution were added and shaken well. After $20 \mathrm{~min}$, the mixture was diluted to the 50 -mL mark, and the spectrophotometer was colorimetric at $578 \mathrm{~nm}$ (the blue of indophenol remained stable). Urease activity was calculated by subtracting the absorbance value of the sample from the difference in the absorbance value of the control sample, and the ammonia nitrogen $\left(\mathrm{NH}_{4}{ }^{+}-\mathrm{N}\right)$ content was calculated according to the standard curve.

The activity of urease was represented by the $\mathrm{NH}_{3}-\mathrm{N}$ content (measured in milligrams) in $1 \mathrm{~g}$ of soil after $24 \mathrm{~h}$. The formula for determining soil urease activity is as follows:

$$
\text { Urease }=\frac{a \times V \times n}{m},
$$

where $a$ is the concentration of $\mathrm{NH}_{4}{ }^{+}-\mathrm{N}$ obtained from the standard curve (measured in milligrams per milliliter), $V$ is the volume of the chromatic liquid $(50 \mathrm{~mL}) ; n$ is the separation multiple; and $m$ is the weight of the drying soil (measured in grams).

Soil phosphatase activity. Soil phosphatase activity was determined by conducting a colorimetric assay with disodium phenyl phosphate (Du et al., 2017). First, 5-g, airdried soil samples were placed in a $200-\mathrm{mL}$ triangulation flask, and $2.5 \mathrm{~mL}$ of toluene was added. After shaking for $15 \mathrm{~min}, 20 \mathrm{~mL}$ of $0.5 \%$ benzene-disodium phosphate was added. After shaking, the samples were placed in an incubator and cultured at $37{ }^{\circ} \mathrm{C}$ for $24 \mathrm{~h}$. Next, $100 \mathrm{~mL}$ of $0.3 \%$ aluminum sulfate solution was added to the culture medium and filtered. Three milliliters of filtrate was then absorbed into $50-\mathrm{mL}$ volumetric bottles, and $5 \mathrm{~mL}$ of buffer solution and four drops of chlorodibromo-p-benzoquinone imines reagent were added to each bottle. After color development, the solution was diluted to the scale, and the colorimetric determination was conducted 30 min later. The boric acid buffer was blue and colorimetric at $660 \mathrm{~nm}$ on the spectrophotometer. To draw the standard curves, $1,3,5,7,9,11$, and $13 \mathrm{~mL}$ of phenolic working fluids were taken for color development and volume determination. After color stability was achieved, the standard curve was drawn with the colorimetric method. Phosphatase activity was expressed in phenolic micrograms per gram of soil.

The activity of phosphatase was represented by the phenol content (measured in milligrams) in $1 \mathrm{~g}$ of soil after $24 \mathrm{~h}$. The formula for determining soil phosphatase activity is as follows:

$$
\text { Phosphatase }=\frac{a \times V \times n}{m},
$$

where $a$ is the concentration of phenol obtained from the standard curve (measured in milligrams per milliliter), $V$ is the volume of the chromatic liquid $(50 \mathrm{~mL}) ; n$ is the separation multiple, and $m$ is the weight of the drying soil (measured in grams).

Soil sucrase activity. Soil sucrase activity was determined by conducting a colorimetric assay with 3,5-dinitrosalicylic acid (Du et al., 2017). First, 5-g, air-dried soil samples were placed in a $50-\mathrm{mL}$ triangulated flask, and 10 $\mathrm{mL}$ of $1 \%$ starch solution was injected. This was followed by the addition of $10 \mathrm{~mL}$ of $\mathrm{pH}$ 5.6 phosphate buffer solution and five drops of toluene, shaking, and storage in an incubator. The samples were then cultured at $37^{\circ} \mathrm{C}$ for $24 \mathrm{~h}$. After culture, the suspension was filtered. Next, $1 \mathrm{~mL}$ of filtrate was poured into a $50-\mathrm{mL}$ volumetric flask. Two milliliters of 3,5-dinitrosalicylic acid solution was added and heated in a boiling water bath for 5 min; the solution was then moved to the volumetric flask and placed in running water

\begin{tabular}{|c|c|c|c|c|c|c|}
\hline Soil texture & $\mathrm{NO}_{3}{ }^{-}-\mathrm{N}\left(\mathrm{mg} \cdot \mathrm{kg}^{-1}\right)$ & $\mathrm{NH}_{4}^{+}-\mathrm{N}\left(\mathrm{mg} \cdot \mathrm{kg}^{-1}\right)$ & Available K $\left(\mathrm{mg} \cdot \mathrm{kg}^{-1}\right)$ & Available P $\left(\mathrm{mg} \cdot \mathrm{kg}^{-1}\right)$ & Organic matter $\left(\mathrm{g} \cdot \mathrm{kg}^{-1}\right)$ & $\mathrm{pH}$ \\
\hline Brown loam & 40.2 & 6.3 & 86.5 & 11.3 & 9.8 & 6.34 \\
\hline
\end{tabular}

Table 1. Basic characteristics of the soil.

$\mathrm{NH}_{4}{ }^{+}-\mathrm{N}=$ ammonium nitrogen; $\mathrm{NO}_{3}{ }^{-} \mathrm{N}=$ nitrate nitrogen; $\mathrm{K}=$ potassium; $\mathrm{P}=$ phosphorus. 
Table 2. Costs of different fumigant treatments.

\begin{tabular}{|c|c|c|c|c|}
\hline Treatment & Name of fumigant & Fumigation agents $\left(\$ / \mathrm{hm}^{2}\right)$ & Plastic film $\left(\$ / \mathrm{hm}^{2}\right)$ & Total $\left(\$ / \mathrm{hm}^{2}\right)$ \\
\hline $\mathrm{T} 1$ & Metham sodium & 183.7 & 459.3 & 643.0 \\
\hline $\mathrm{T} 3$ & Calcium cyanamide & 344.5 & 459.3 & 803.8 \\
\hline T4 & 1,3-Dichloropropene & 803.8 & 459.3 & $1,263.1$ \\
\hline
\end{tabular}

to cool. After a constant volume of $50 \mathrm{~mL}$ was achieved, colorimetry was performed at $508 \mathrm{~nm}$ on a spectrophotometer. Glucose solution was used as the standard.

The activity of sucrase was represented by the glucose content (measured in milligrams) in $1 \mathrm{~g}$ of soil after $24 \mathrm{~h}$. The formula for determining soil sucrase activity is as follows:

$$
\text { Sucrase }=\frac{a \times V \times n}{m},
$$

where $a$ is the concentration of glucose obtained from the standard curve (measured in milligrams per milliliter), $V$ is the volume of the chromatic liquid $(50 \mathrm{~mL}), n$ is the separation multiple, and $m$ is the weight of the drying soil (measured in grams).

Soil catalase activity. The soil catalase activity was determined by potassium permanganate $\left(\mathrm{KMnO}_{4}\right)$ titration ( $\mathrm{Du}$ et al., 2017). First, 2-g, air-dried soil samples were placed in a $100-\mathrm{mL}$ trigonometric bottle and injected with $40 \mathrm{~mL}$ of distilled water and $5 \mathrm{~mL}$ of $0.3 \%$ hydrogen peroxide $\left(\mathrm{H}_{2} \mathrm{O}_{2}\right)$ solution. A control $(40 \mathrm{~mL}$ of distilled water and $5 \mathrm{~mL}$ of $0.3 \% \mathrm{H}_{2} \mathrm{O}_{2}$ solution) was injected into a triangular bottle without the addition of soil samples. The triangular bottle was shaken on a shaking machine for $20 \mathrm{~min}$, and $5 \mathrm{~mL}$ of $3 \mathrm{~N}$ sulfuric acid was added to stabilize the undecomposed $\mathrm{H}_{2} \mathrm{O}_{2}$. The suspension in the bottle was then filtered with a slow filter paper, followed by absorption of 25 $\mathrm{mL}$ of filtrate and titration with $0.1 \mathrm{~N}$ $\mathrm{KMnO}_{4}$ to the light-pink terminal point.

The activity of catalase was represented by volume (measured in milliliters) of $0.1 \mathrm{~N}$ $\mathrm{KMnO}_{4}$ in $1 \mathrm{~g}$ of soil after $20 \mathrm{~min}$. The formula for determining soil catalase activity is as follows:

$$
\text { Catalase }=(A-B) \times T,
$$

where $B$ is the amount of $\mathrm{KMnO}_{4}$ (measured in milliliters) consumed for titrating the soil filtrate (measured in milliliters), $A$ is the amount of $\mathrm{KMnO}_{4}$ (measured in milliliters) consumed for titrating $25 \mathrm{~mL}$ of the original $\mathrm{H}_{2} \mathrm{O}_{2}$ mixture (measured in milliliters), and $T$ is the correction value for $\mathrm{KMnO}_{4}$ titration.

\section{Soil culturable microorganisms}

Soil microbial numbers were determined by a conventional plate count method. Bacteria were cultured in beef extract peptone medium (containing beef extract, peptone, and sodium chloride). The plates were inverted and cultured at $28{ }^{\circ} \mathrm{C}$ for 24 to $48 \mathrm{~h}$ before observing and counting colonies. Fungi were cultured in Martin medium (containing potassium dihydrogen phos- phate, anhydrous magnesium sulfate, and peptone). The plates were inverted and cultured at $28{ }^{\circ} \mathrm{C}$ for 48 to $72 \mathrm{~h}$ before observing and counting colonies. Actinomycetes were cultured with Gauze's Medium No. 1 (containing potassium nitrate, dipotassium hydrogen phosphate, and anhydrous magnesium sulfate). The plates were inverted and cultured at $28^{\circ} \mathrm{C}$ for 72 to $96 \mathrm{~h}$ before observing and counting colonies. The soil microbial number per gram of dry soil (colonyforming unit) = Average number of colonies $\times$ Dilution factor/dry weight of soil sample.

\section{Soil microbial community structure}

The extraction and purification of total DNA from the sample genome was performed per the instructions of the E.Z.N.A. Soil DNA Kit (Omega Bio-Tek, Norcross, GA). The

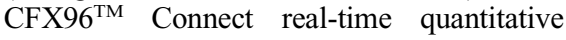
PCR system (BIO-RAD, Hercules, CA) was used to analyze the copy number of Fusarium oxysporum genes in the soil by real-time quantitative PCR. The system was implemented per the instructions of the SYBR Premix Ex TaqTM Kit (TaKaRa Biotech Co., Ltd., Dalian, China). Each reaction with the $25-\mu \mathrm{L}$ PCR system included $1.5 \mu \mathrm{L}$ DNA template, $12.5 \mu \mathrm{L}$ SYBR Premix Ex TaqII (TaKaRa Biotech Co.), $1 \mu \mathrm{L}$ of each primer; and $9 \mu \mathrm{L}$ double distilled water. Reaction procedures involved predenaturation at $95{ }^{\circ} \mathrm{C}$ for $30 \mathrm{~s}$, denaturation at $95{ }^{\circ} \mathrm{C}$ for $5 \mathrm{~s}$, and annealing at $60{ }^{\circ} \mathrm{C}$ for $30 \mathrm{~s}$, for a total of 40 cycles.

\section{Plant biomass}

Samples were taken at $52 \mathrm{~d}(45 \mathrm{~d}$ after seedlings were planted), $112 \mathrm{~d}$ (105 d after seedlings were planted), and $172 \mathrm{~d}(165 \mathrm{~d}$ after seedlings were planted) after fumigation. At each sampling event, three $M$. hupehensis Rehd. seedlings were taken for each treatment and washed in clean water. Measurements of seedling height, ground diameter, and fresh weight were then acquired by using a ruler, vernier calipers, and electronic scale, respectively. After measurements, $M$. hupehensis Rehd. seedlings were wrapped tightly in paper bags and placed in a constanttemperature oven. After drying, seedlings were removed carefully and the dry mass was measured with an electronic scale.

\section{Root configuration parameters}

Samples were taken at $52 \mathrm{~d}(45 \mathrm{~d}$ after seedlings were planted), $112 \mathrm{~d}$ (105 d after seedlings were planted), and $172 \mathrm{~d}$ (165 d after seedlings were planted) after fumigation. At each sampling event, three $M$. hupehensis Rehd. seedlings were taken for each treatment. Roots were then washed in clean
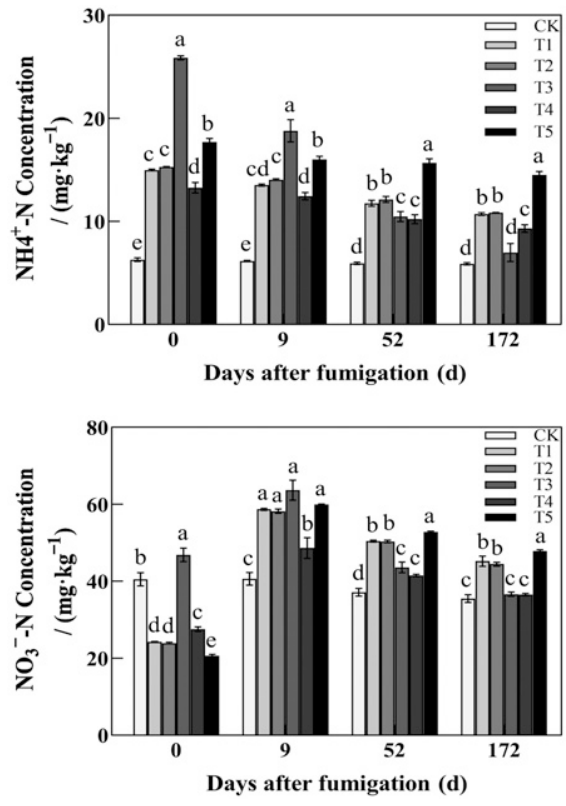

Fig. 1. Effects of ammonium nitrogen (top) and nitrate nitrogen (bottom) content in soil under different fumigant treatments at each sampling event. The number of days after fumigation starts the day when the plastic film was opened. Note that $0 \mathrm{~d}, 9 \mathrm{~d}, 52 \mathrm{~d}$, and $172 \mathrm{~d}$ refer to $0 \mathrm{~d}, 9$ d, $52 \mathrm{~d}$, and $172 \mathrm{~d}$, respectively, since the opening of the plastic film, which corresponds to $0 \mathrm{~d}, 2 \mathrm{~d}, 45 \mathrm{~d}$, and $165 \mathrm{~d}$, respectively, after Malus hupehensis Rehd. seedlings were planted. Data are mean \pm SE $(n=3)$. Values in the same column marked with the same letter are not significantly different at $P<0.05$ according to Duncan's new multiple range test. $\mathrm{NH}_{4}{ }^{+} \mathrm{N}$, ammonium nitrogen; $\mathrm{NO}_{3}{ }^{-} \mathrm{N}$, nitrate nitrogen; CK, control check; T1, metham sodium; T2, dazomet; T3, calcium cyanamide; T4, 1,3-dichloropropene; T5, methyl bromide.

water, laid flat on a hard plastic container, and spread out in the water. The WinRHIZO root analysis system (version 2007; Seiko Epson Corporation, Nagano Prefecture, Japan) was then used to measure the root length, total volume, total surface area, and root tip number of seedlings from the sample images.

\section{Root respiration rate}

Samples were taken at $52 \mathrm{~d}(45 \mathrm{~d}$ after seedlings were planted), $112 \mathrm{~d}$ (105 d after seedlings were planted), and $172 \mathrm{~d}$ (165 d after seedlings were planted) after fumigation. At each sampling event, three $M$. hupehensis Rehd. seedlings were taken for each treatment. Roots were then washed in clean water, and $0.5 \mathrm{~g}$ of fresh white roots was taken from the seedling roots and divided 
evenly into 0.1-cm segments. An Oxytherm oxygen electrode (Hansatech Instruments Ltd, Pentney, UK) was used to determine the root respiration rate.

\section{Statistical analysis}

The experimental data were calculated and plotted using Microsoft Excel 2003. Analysis of variance was performed using SPSS19.0 software (version 19.0; SPSS Inc., Chicago, IL), and significant differences were detected by Duncan's new complex range method.

\section{Results}

\section{$\mathrm{NH}_{4}{ }^{+}-\mathrm{N}$ and $\mathrm{NO}_{3}{ }^{-}-\mathrm{N}$ content in soil}

On the day after exposure, the $\mathrm{NH}_{4}{ }^{+}-\mathrm{N}$ content of each treatment differed significantly from the continuous control (Fig. 1). The $\mathrm{NH}_{4}{ }^{+}-\mathrm{N}$ content of $\mathrm{T} 1, \mathrm{~T} 2, \mathrm{~T} 3, \mathrm{~T} 4$, and T5 was increased by $1.38 \%, 1.43 \%, 3.12 \%$, $1.11 \%$, and $1.82 \%$, respectively, compared with the control. At $9 \mathrm{~d}, 52 \mathrm{~d}$, and $172 \mathrm{~d}$ after fumigation, the $\mathrm{NH}_{4}{ }^{+}-\mathrm{N}$ content of each treatment was consistently greater than that of the control, and differences between the treatments and the control were significant. On the day after exposure, the content of $\mathrm{NO}_{3}{ }^{-}-\mathrm{N}$ in $\mathrm{T} 1, \mathrm{~T} 2, \mathrm{~T} 3, \mathrm{~T} 4$, and T5 was 0.60 times, 0.59 times, 1.16 times, 0.68 times, and 0.51 times greater, respectively, compared with the control. Nine days after fumigation, the $\mathrm{NO}_{3}{ }^{-}-\mathrm{N}$ content of each treatment increased; specifically, the content of (bromomethane) $\mathrm{NO}_{3}{ }^{-}-\mathrm{N}$ for $\mathrm{T} 1, \mathrm{~T} 2, \mathrm{~T} 3, \mathrm{~T} 4$, and $\mathrm{T} 5$ was 1.45 times, 1.43 times, 1.57 times, 1.20 times, and 1.48 times greater, respectively, than that of the control. The $\mathrm{NO}_{3}{ }^{-}-\mathrm{N}$ content of each treatment decreased over time, and the $\mathrm{NO}_{3}{ }^{-} \mathrm{N}$ content was always greater than the control.

\section{Soil enzyme activity}

The enzyme activity of soil treated with the five fumigants was significantly less than
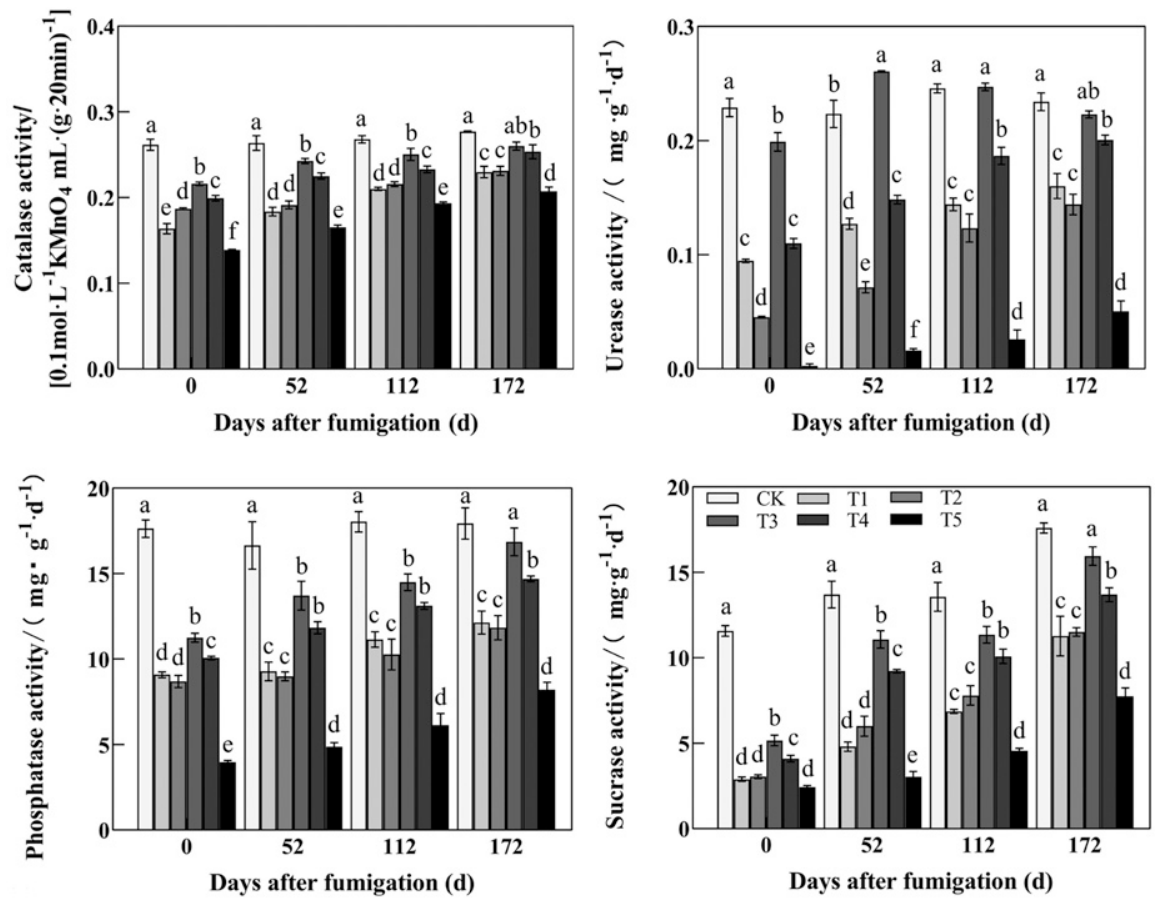

Fig. 2. Effects of different fumigant treatments on soil enzyme activities at each sampling event. (Upper left) Soil catalase activity. (Upper right) Soil urease activity. (Lower left) Soil phosphatase activity. (Lower right) Soil sucrase activity. The number of days after fumigation starts the day when the plastic film was opened. Note that $0 \mathrm{~d}, 52 \mathrm{~d}, 112 \mathrm{~d}$, and $172 \mathrm{~d}$ refer to $0 \mathrm{~d}, 52 \mathrm{~d}, 112 \mathrm{~d}$, and $172 \mathrm{~d}$, respectively, since the opening of the plastic film, which corresponds to $0 \mathrm{~d}, 45 \mathrm{~d}, 105 \mathrm{~d}$, and $165 \mathrm{~d}$, respectively, after Malus hupehensis Rehd. seedlings were planted. Data are mean $\pm \mathrm{SE}(\mathrm{n}=3)$. Values marked with the same letter within a sampling event are not significantly different at $P<0.05$ according to Duncan's new multiple range test. $\mathrm{KMnO}_{4}$, potassium permanganate; $\mathrm{CK}$, control check; T1, metham sodium; T2, dazomet; T3, calcium cyanamide; T4, 1,3-dichloropropene; T5, methyl bromide.

that of the control group (Fig. 2). The most obvious inhibitory effect on urease activity was observed in $\mathrm{T} 5$, followed by $\mathrm{T} 2, \mathrm{~T} 1, \mathrm{~T} 4$, and T3. On the first day after exposure, the urease activity of $\mathrm{T} 1, \mathrm{~T} 2, \mathrm{~T} 3, \mathrm{~T} 4$, and $\mathrm{T} 5$ decreased by $58.66 \%, 80.24 \%, 13.10 \%$, $52.02 \%$, and $98.87 \%$, respectively, compared with that of the control group, and differences between each treatment and the control were significant. The urease enzyme activity was restored gradually $52 \mathrm{~d}, 112 \mathrm{~d}$, and $172 \mathrm{~d}$ after fumigation.

The day after the plastic film was removed, the $\mathrm{H}_{2} \mathrm{O}_{2}$ enzyme activity in $\mathrm{T} 1$, $\mathrm{T} 2$, T3, T4, and T5 was reduced by $37.45 \%$, $28.54 \%, 17.45 \%, 23.82 \%$, and $46.88 \%$, respectively, compared with the control. The $\mathrm{H}_{2} \mathrm{O}_{2}$ enzyme activity was restored gradually $52 \mathrm{~d}, 112 \mathrm{~d}$, and $172 \mathrm{~d}$ after fumigation.

On the day after exposure, the phosphatase activity of each treatment was reduced by $48.50 \%, 50.72 \%, 36.23 \%, 42.92 \%$, and $77.48 \%$, respectively, compared with the control group. At $172 \mathrm{~d}$ after fumigation, there was no significant difference in phosphatase activity between $\mathrm{T} 3$ and the control group, and the phosphatase activity of each treatment was still in a state of recovery and increasing. The pattern of change in the sucrase activity and phosphatase activity was nearly the same.

\section{Number of microorganisms}

The five fumigant treatments reduced significantly the number of soil fungi and bacteria (Table 4). The number of soil bacteria and fungi increased with time, and the growth rate of bacteria was more rapid than that of fungi. On the day after exposure, the number of bacteria, the number of fungi, and the ratio of bacteria to fungi between treatments differed significantly from the control. At $112 \mathrm{~d}$ after fumigation, the number of bacteria in $\mathrm{T} 1, \mathrm{~T} 2, \mathrm{~T} 3, \mathrm{~T} 4$, and $\mathrm{T} 5$ was increased by $51.17 \%, 58.14 \%, 20.93 \%$, $41.86 \%$, and $102.33 \%$, respectively, compared with the control. At $172 \mathrm{~d}$ after fumigation, the number of bacteria and fungi in each treatment continued to increase, and each treatment still differed significantly from the control.

\section{Gene copies of Fusarium oxysporum}

The copy number of Fusarium oxysporum genes in the soil at different periods was analyzed using real-time PCR. Each treatment reduced significantly the soil Fusarium oxysporum gene copy number, including sharp spores, $0 \mathrm{~d}$ after fumigation (Fig. 3). For example, for T1, $\mathrm{T} 2, \mathrm{~T} 3, \mathrm{~T} 4$, and $\mathrm{T} 5$, the gene copy number

Table 3. Name of fumigant, source, dosage form, and recommended concentration under different fumigant treatments.

\begin{tabular}{|c|c|c|c|c|}
\hline Treatment & Name of fumigant & Dosage form & Recommended concn $\left(\mathrm{kg} \cdot \mathrm{hm}^{-2}\right)$ & Source \\
\hline $\mathrm{T} 1$ & Metham sodium & Agent & 90.0 & Jiangsu LIMIN Chemical Co., Ltd. \\
\hline $\mathrm{T} 2$ & Dazomet & Particle agent & 600.0 & Jiangsu Nantong Shizhuang Chemical Co., Ltd. \\
\hline T3 & Calcium cyanamide & Granules & 1500.0 & Ningxia Jiafeng Chemical Co., Ltd. \\
\hline $\mathrm{T} 4$ & 1,3-Dichloropropene & EC reagent & 450.0 & Hunan Levante Chemical Co., Ltd. \\
\hline T5 & Methyl bromide & Gas preparation & - & Jiangsu Lianyungang Dead Sea Bromide Co., Ltd \\
\hline
\end{tabular}


Table 4. Effects of different fumigant treatments on the number of microorganisms at each sampling event.

\begin{tabular}{|c|c|c|c|c|}
\hline$\overline{\text { Day }}$ & Treatment & Bacteria $\left(\times 10^{5} \mathrm{cfu} / \mathrm{g}\right)$ & Fungi $\left(\times 10^{3} \mathrm{cfu} / \mathrm{g}\right)$ & Bacteria/fungi \\
\hline \multirow[t]{6}{*}{$0^{z} d$} & CK & $12.33 \pm 0.33^{\mathrm{y}} \mathrm{a}^{\mathrm{x}}$ & $33.00 \pm 2.52 \mathrm{a}$ & $37.64 \pm 1.75 \mathrm{c}$ \\
\hline & $\mathrm{T} 1$ & $2.67 \pm 0.67 \mathrm{~d}$ & $1.33 \pm 0.33 \mathrm{~d}$ & $200.00 \pm 0.00 \mathrm{a}$ \\
\hline & $\mathrm{T} 2$ & $3.00 \pm 0.58 \mathrm{~d}$ & $1.00 \pm 0.58 \mathrm{~d}$ & $133.33 \pm 66.67 \mathrm{ab}$ \\
\hline & T3 & $8.00 \pm 0.58 b$ & $12.33 \pm 0.67 b$ & $64.80 \pm 2.29 b c$ \\
\hline & $\mathrm{T} 4$ & $6.00 \pm 0.58 \mathrm{c}$ & $7.00 \pm 0.58 \mathrm{c}$ & $86.31 \pm 8.27 b c$ \\
\hline & T5 & $0.67 \pm 0.33 \mathrm{e}$ & $0.33 \pm 0.33 \mathrm{~d}$ & $0.00 \pm 0.00 \mathrm{c}$ \\
\hline \multirow[t]{6}{*}{$52 \mathrm{~d}$} & CK & $12.33 \pm 0.33 b c$ & $36.00 \pm 2.65 \mathrm{a}$ & $34.64 \pm 2.69 \mathrm{c}$ \\
\hline & $\mathrm{T} 1$ & $12.67 \pm 0.33 \mathrm{~b}$ & $5.33 \pm 0.33 \mathrm{c}$ & $238.89 \pm 12.52 \mathrm{~b}$ \\
\hline & $\mathrm{T} 2$ & $11.67 \pm 1.33 \mathrm{bc}$ & $4.33 \pm 0.67 \mathrm{c}$ & $273.33 \pm 13.33 \mathrm{~b}$ \\
\hline & T3 & $10.33 \pm 0.33 \mathrm{c}$ & $15.00 \pm 0.58 \mathrm{~b}$ & $69.09 \pm 3.34 \mathrm{c}$ \\
\hline & $\mathrm{T} 4$ & $10.67 \pm 0.33 b c$ & $11.33 \pm 1.33 b$ & $96.19 \pm 9.27 \mathrm{c}$ \\
\hline & T5 & $14.67 \pm 0.33 \mathrm{a}$ & $2.33 \pm 0.33 \mathrm{c}$ & $655.56 \pm 94.44 \mathrm{a}$ \\
\hline \multirow[t]{6}{*}{$112 \mathrm{~d}$} & CK & $14.33 \pm 0.33 \mathrm{~d}$ & $45.33 \pm 2.73 \mathrm{a}$ & $31.83 \pm 1.86 \mathrm{c}$ \\
\hline & $\mathrm{T} 1$ & $21.67 \pm 0.33 b$ & $7.67 \pm 0.33 \mathrm{~d}$ & $283.93 \pm 15.60 \mathrm{~b}$ \\
\hline & $\mathrm{T} 2$ & $22.67 \pm 0.88 b$ & $7.33 \pm 0.67 \mathrm{~d}$ & $315.28 \pm 35.71 \mathrm{~b}$ \\
\hline & T3 & $17.33 \pm 0.33 \mathrm{c}$ & $24.33 \pm 0.88 b$ & $71.32 \pm 1.37 \mathrm{c}$ \\
\hline & $\mathrm{T} 4$ & $20.33 \pm 1.33 b$ & $17.67 \pm 1.20 \mathrm{c}$ & $115.17 \pm 2.02 \mathrm{c}$ \\
\hline & T5 & $29.00 \pm 1.53 \mathrm{a}$ & $4.33 \pm 0.33 \mathrm{~d}$ & $681.67 \pm 81.25 \mathrm{a}$ \\
\hline \multirow[t]{6}{*}{$172 \mathrm{~d}$} & $\mathrm{CK}$ & $14.00 \pm 0.58 \mathrm{~d}$ & $50.00 \pm 0.58 \mathrm{a}$ & $27.99 \pm 1.03 \mathrm{c}$ \\
\hline & $\mathrm{T} 1$ & $34.00 \pm 0.58 b$ & $11.67 \pm 0.33 \mathrm{~d}$ & $292.17 \pm 13.23 b$ \\
\hline & $\mathrm{T} 2$ & $35.00 \pm 0.58 b$ & $10.00 \pm 0.58 \mathrm{~d}$ & $352.73 \pm 24.46 b$ \\
\hline & T3 & $29.33 \pm 0.33 \mathrm{c}$ & $29.67 \pm 0.88 b$ & $99.00 \pm 2.28 \mathrm{c}$ \\
\hline & $\mathrm{T} 4$ & $31.33 \pm 0.33 b c$ & $12.33 \pm 0.88 \mathrm{c}$ & $140.75 \pm 5.82 \mathrm{c}$ \\
\hline & T5 & $46.00 \pm 3.21 \mathrm{a}$ & $6.33 \pm 0.33 \mathrm{e}$ & $734.92 \pm 83.98 \mathrm{a}$ \\
\hline
\end{tabular}

${ }^{\mathrm{z}}$ The number of days after fumigation starts the day when the plastic film was opened. Note that $0 \mathrm{~d}, 52 \mathrm{~d}, 112 \mathrm{~d}$, and $172 \mathrm{~d}$ refer to $0 \mathrm{~d}, 52 \mathrm{~d}, 112 \mathrm{~d}$, and $172 \mathrm{~d}$, respectively, since the opening of the plastic film, which corresponds to $0 \mathrm{~d}, 45 \mathrm{~d}, 105 \mathrm{~d}$, and $165 \mathrm{~d}$, respectively, after Malus hupehensis Rehd. seedlings were planted.

${ }^{\mathrm{y}}$ Data are mean $\pm \mathrm{SE}(\mathrm{n}=3)$.

${ }^{\mathrm{x}}$ Values in the same column marked with the same letter are not significantly different at $P<0.05$ according to Duncan's new multiple range test.

$\mathrm{cfu}=$ colony-forming unit; $\mathrm{CK}=$ control check; $\mathrm{T} 1$ = metham sodium; $\mathrm{T} 2$ = dazomet; $\mathrm{T} 3=$ calcium cyanamide; $\mathrm{T} 4=1,3-\mathrm{dichloropropene}$; 5 = methyl bromide .

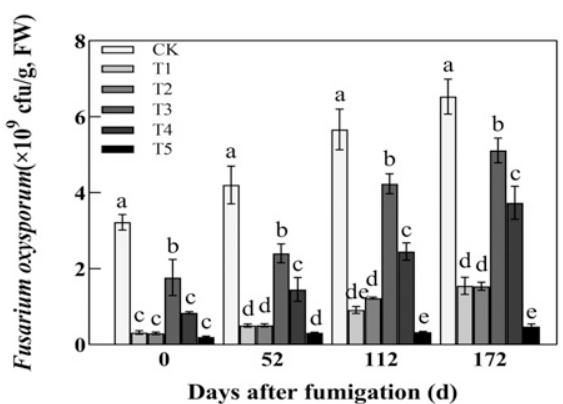

Fig. 3. Effects of different fumigant treatments on the gene copies of Fusarium oxysporum at each sampling event. The number of days after fumigation starts the day when the plastic film was opened. Note that $0 \mathrm{~d}, 52 \mathrm{~d}, 112 \mathrm{~d}$, and $172 \mathrm{~d}$ refer to $0 \mathrm{~d}, 52 \mathrm{~d}, 112 \mathrm{~d}$, and $172 \mathrm{~d}$, respectively, since the opening of the plastic film, which corresponds to $0 \mathrm{~d}, 45 \mathrm{~d}, 105 \mathrm{~d}$, and $165 \mathrm{~d}$, respectively, after Malus hupehensis Rehd. seedlings were planted. Data are mean $\pm \mathrm{SE}(\mathrm{n}=3)$. Values marked with the same letter within a sampling event are not significantly different at $P<0.05$ according to Duncan's new multiple range test. cfu, colony-forming unit; FW, fresh weight; CK, control check; T1, metham sodium; T2, dazomet; T3, calcium cyanamide; T4, 1,3-dichloropropene; T5, methyl bromide.

of Fusarium oxysporum, was reduced by $90.11 \%, 90.82 \%, 45.17 \%, 74.11 \%$, and $93.80 \%$, respectively, compared with the control. Over time, the pointed spores all tended to restore the Fusarium oxysporum gradually. The pointed spore number of the Fusarium copy methyl bromide treat- ment (T5) was always the lowest. In addition, the recovery rate was the slowest for T5 and was significantly different from the control, followed by $\mathrm{T} 2, \mathrm{~T} 1$, $\mathrm{T} 4$, and $\mathrm{T} 3$.

\section{Biomass of Malus hupehensis Rehd. seedlings}

Soil fumigation promoted the growth of $M$. hupehensis Rehd. seedlings, and different fumigants had different effects on the observed growth at different stages (Table 5). At $52 \mathrm{~d}$ after the end of fumigation, the growth of plants under each treatment was significantly different from that of the control. The height of the M. hupehensis Rehd. seedlings under T1, T2, T3, T4, and T5 increased by $42.83 \%, 41.57 \%, 19.97 \%$, $26.26 \%$, and $88.73 \%$, respectively, compared with the control. At $112 \mathrm{~d}$ and $172 \mathrm{~d}$ after fumigation, the growth of plants under each treatment was still significantly different from that of the control. At $172 \mathrm{~d}$ after the end of fumigation, the height of the $M$. hupehensis Rehd. seedlings under $\mathrm{T} 1, \mathrm{~T} 2$, $\mathrm{T} 3$, T4, and T5 increased by $91.64 \%$, $85.34 \%, 39.00 \%, 28.88 \%$, and $110.5 \%$, respectively.

\section{Root growth of Malus hupehensis Rehd. seedlings}

Different fumigant treatments promoted the root growth of $M$. hupehensis Rehd. seedlings to different degrees (Table 6). After $52 \mathrm{~d}$ of fumigation in $\mathrm{T} 1, \mathrm{~T} 2, \mathrm{~T} 3, \mathrm{~T} 4$, and T5, the root length of the seedlings increased by $82.37 \%, 81.72 \%, 62.00 \%, 69.03 \%$, and $117.50 \%$, respectively, compared with the control. The root surface, root volume, and root tip also increased significantly compared with the control. After $112 \mathrm{~d}$ and $172 \mathrm{~d}$ of fumigation, the root growth of $M$. hupehensis Rehd. seedlings under each treatment tended to be stable, but still differed significantly from the control.

Figure 4 shows that the five fumigation agents significantly improved the $M$. hupehensis Rehd. seedling root respiration rate $52 \mathrm{~d}$ after fumigation. The root respiration rate for T1 and T2 was significantly different from that of the control, but the root respiration rate for $\mathrm{T} 1$ and $\mathrm{T} 2$ did not differ significantly. At $112 \mathrm{~d}$ after fumigation, each of the five treatments differed significantly from the control with regard to root respiration rate; however, $\mathrm{T} 1$ and $\mathrm{T} 2$ did not differ significantly. The pattern in the root respiration rate observed at $172 \mathrm{~d}$ after fumigation was the same as that observed at $112 \mathrm{~d}$ after fumigation.

\section{Discussion}

Several years of agricultural production have shown that soil fumigation is the most effective measure for alleviating replant disease (Ren et al., 2018). On the one hand, soil fumigation can improve the soil environment by altering microbial community structure (Su et al., 2020); on the other hand, it can promote the growth of plants by improving soil physicochemical properties (Shao et al., 2015).

\section{Soil physicochemical properties}

Plant growth is related closely to the soil environment. Soil enzyme activity is an important factor for evaluating the level of 
Table 5. Effects of different fumigants on the biomass of Malus hupehensis Rehd. seedlings at each sampling event.

\begin{tabular}{|c|c|c|c|c|c|}
\hline Days & Treatment & Plant ht $(\mathrm{cm})$ & Ground diam $(\mathrm{mm})$ & Fresh wt (g) & Dry wt (g) \\
\hline \multirow[t]{6}{*}{$52^{z} d$} & CK & $15.88 \pm 0.25^{y} d^{x}$ & $2.32 \pm 0.01 \mathrm{e}$ & $19.88 \pm 0.23 \mathrm{~d}$ & $9.87 \pm 0.11 \mathrm{~d}$ \\
\hline & $\mathrm{T} 1$ & $22.68 \pm 0.56 b$ & $2.74 \pm 0.05 b$ & $27.01 \pm 0.55 b$ & $13.25 \pm 0.27 b$ \\
\hline & $\mathrm{T} 2$ & $22.48 \pm 0.39 b$ & $2.63 \pm 0.02 \mathrm{bc}$ & $26.81 \pm 0.67 b$ & $13.15 \pm 0.08 \mathrm{~b}$ \\
\hline & T3 & $19.05 \pm 0.36 \mathrm{c}$ & $2.45 \pm 0.08 \mathrm{~d}$ & $24.21 \pm 0.95 \mathrm{c}$ & $12.05 \pm 0.48 \mathrm{c}$ \\
\hline & $\mathrm{T} 4$ & $20.05 \pm 0.10 \mathrm{c}$ & $2.53 \pm 0.04 \mathrm{~cd}$ & $24.38 \pm 0.40 \mathrm{c}$ & $12.06 \pm 0.19 \mathrm{c}$ \\
\hline & T5 & $29.96 \pm 1.05 \mathrm{a}$ & $3.23 \pm 0.02 \mathrm{a}$ & $33.96 \pm 1.06 \mathrm{a}$ & $16.79 \pm 0.53 \mathrm{a}$ \\
\hline \multirow[t]{6}{*}{$112 \mathrm{~d}$} & $\mathrm{CK}$ & $35.42 \pm 1.24 \mathrm{e}$ & $3.62 \pm 0.01 \mathrm{e}$ & $39.42 \pm 1.24 \mathrm{e}$ & $19.04 \pm 0.77 \mathrm{e}$ \\
\hline & $\mathrm{T} 1$ & $62.72 \pm 0.23 b$ & $8.21 \pm 0.01 \mathrm{~b}$ & $68.46 \pm 0.32 b$ & $33.16 \pm 0.52 b$ \\
\hline & $\mathrm{T} 2$ & $60.19 \pm 1.12 b$ & $8.14 \pm 0.06 b$ & $65.05 \pm 1.47 \mathrm{~b}$ & $31.49 \pm 0.57 \mathrm{~b}$ \\
\hline & T3 & $41.17 \pm 1.15 \mathrm{~d}$ & $3.79 \pm 0.01 \mathrm{~d}$ & $44.84 \pm 0.88 \mathrm{~d}$ & $21.33 \pm 0.37 \mathrm{~d}$ \\
\hline & $\mathrm{T} 4$ & $46.85 \pm 2.44 \mathrm{c}$ & $4.07 \pm 0.02 \mathrm{c}$ & $50.85 \pm 2.44 \mathrm{c}$ & $24.65 \pm 0.85 \mathrm{c}$ \\
\hline & T5 & $68.12 \pm 1.76 \mathrm{a}$ & $9.13 \pm 0.02 \mathrm{a}$ & $74.65 \pm 0.58 \mathrm{a}$ & $35.46 \pm 0.24 \mathrm{a}$ \\
\hline \multirow[t]{6}{*}{$172 \mathrm{~d}$} & $\mathrm{CK}$ & $45.10 \pm 3.06 \mathrm{e}$ & $3.95 \pm 0.02 \mathrm{e}$ & $49.10 \pm 3.05 \mathrm{e}$ & $24.30 \pm 1.49 \mathrm{e}$ \\
\hline & $\mathrm{T} 1$ & $86.43 \pm 0.52 b$ & $11.32 \pm 0.01 \mathrm{~b}$ & $91.68 \pm 1.45 b$ & $45.09 \pm 1.00 \mathrm{~b}$ \\
\hline & $\mathrm{T} 2$ & $83.59 \pm 0.57 b$ & $11.21 \pm 0.08 \mathrm{~b}$ & $87.42 \pm 1.33 b$ & $43.06 \pm 0.54 b$ \\
\hline & T3 & $62.69 \pm 4.06 \mathrm{~d}$ & $8.44 \pm 0.02 \mathrm{~d}$ & $66.69 \pm 4.07 \mathrm{~d}$ & $32.86 \pm 2.10 \mathrm{~d}$ \\
\hline & $\mathrm{T} 4$ & $73.98 \pm 4.13 \mathrm{c}$ & $10.05 \pm 0.03 \mathrm{c}$ & $77.98 \pm 4.15 \mathrm{c}$ & $38.51 \pm 1.98 \mathrm{c}$ \\
\hline & T5 & $94.94 \pm 0.39 \mathrm{a}$ & $12.05 \pm 0.02 \mathrm{a}$ & $104.96 \pm 2.06 \mathrm{a}$ & $51.92 \pm 1.03 \mathrm{a}$ \\
\hline
\end{tabular}

${ }^{\mathrm{z}}$ The number of days after fumigation starts the day when the plastic film was opened. Note that $52 \mathrm{~d}, 112 \mathrm{~d}$, and $172 \mathrm{~d}$ refer to $52 \mathrm{~d}, 105 \mathrm{~d}$, and $172 \mathrm{~d}$, respectively, since the opening of the plastic film, which corresponds to $45 \mathrm{~d}, 105 \mathrm{~d}$, and $165 \mathrm{~d}$, respectively, after Malus hupehensis Rehd. seedlings were planted.

${ }^{\mathrm{y}}$ Data are mean $\pm \mathrm{SE}(\mathrm{n}=3)$.

${ }^{\mathrm{x}}$ Values in the same column marked with the same letter are not significantly different at $P<0.05$ according to Duncan's new multiple range test.

$\mathrm{CK}=$ control check; $\mathrm{T} 1$ = metham sodium; $\mathrm{T} 2$ = dazomet; $\mathrm{T} 3=$ calcium cyanamide; $\mathrm{T} 4=1$,3-dichloropropene; $\mathrm{T} 5=$ methyl bromide .

Table 6. Effects of different fumigant treatments on the root growth of Malus hupehensis Rehd. seedlings at each sampling event.

\begin{tabular}{|c|c|c|c|c|c|}
\hline$\overline{\text { Days }}$ & Treatment & Root length $(\mathrm{cm})$ & Root surface area $\left(\mathrm{cm}^{2}\right)$ & Root volume $\left(\mathrm{cm}^{3}\right)$ & Tips per seedling \\
\hline \multirow{3}{*}{$52^{z} d$} & $\mathrm{~T} 2$ & $1,890.27 \pm 46.03 \mathrm{~b}$ & $817.86 \pm 10.46 b$ & $16.27 \pm 0.82 b$ & $2,320.88 \pm 62.69 b$ \\
\hline & $\mathrm{T} 3$ & $1,685.12 \pm 24.12 \mathrm{c}$ & $716.18 \pm 12.07 \mathrm{c}$ & $13.19 \pm 0.35 \mathrm{c}$ & $1,963.44 \pm 79.29 \mathrm{c}$ \\
\hline & T5 & $2,262.40 \pm 75.48 \mathrm{a}$ & $897.21 \pm 26.57 \mathrm{a}$ & $24.00 \pm 1.84 \mathrm{a}$ & $2,961.78 \pm 133.85 \mathrm{a}$ \\
\hline \multirow[t]{4}{*}{$112 \mathrm{~d}$} & CK & $2,596.49 \pm 85.28 \mathrm{e}$ & $1,018.72 \pm 16.16 \mathrm{e}$ & $26.57 \pm 0.64 \mathrm{e}$ & $3,207.84 \pm 120.52 \mathrm{e}$ \\
\hline & $\mathrm{T} 1$ & $4,784.35 \pm 66.52 b$ & $1,282.64 \pm 10.32 b$ & $61.65 \pm 0.81 \mathrm{~b}$ & $6,604.86 \pm 103.93 b$ \\
\hline & $\mathrm{T} 4$ & $3,751.01 \pm 35.75 \mathrm{c}$ & $1,201.77 \pm 10.45 c$ & $32.44 \pm 0.34 \mathrm{c}$ & $4,907.83 \pm 142.12 \mathrm{c}$ \\
\hline & T5 & $5,351.54 \pm 95.06 \mathrm{a}$ & $1,333.48 \pm 16.85 \mathrm{a}$ & $64.75 \pm 1.22 \mathrm{a}$ & $7,138.28 \pm 219.55 \mathrm{a}$ \\
\hline \multirow[t]{5}{*}{$172 \mathrm{~d}$} & CK & $3,686.65 \pm 55.48 \mathrm{e}$ & $1,133.97 \pm 15.25 \mathrm{e}$ & $31.45 \pm 1.74 \mathrm{e}$ & $4,556.90 \pm 132.02 \mathrm{e}$ \\
\hline & $\mathrm{T} 1$ & $7,287.38 \pm 115.97 b$ & $1,646.83 \pm 31.01 \mathrm{~b}$ & $75.24 \pm 1.36 b$ & $8,341.04 \pm 205.02 b$ \\
\hline & $\mathrm{T} 2$ & $7,154.94 \pm 101.06 b$ & $1,627.06 \pm 52.28 b$ & $71.15 \pm 1.16 \mathrm{bc}$ & $8,174.62 \pm 185.29 b$ \\
\hline & T3 & $4,775.10 \pm 60.15 \mathrm{~d}$ & $1,298.67 \pm 19.65 \mathrm{~d}$ & $61.37 \pm 1.58 \mathrm{~d}$ & $6,187.09 \pm 136.95 \mathrm{~d}$ \\
\hline & $\mathrm{T} 4$ & $5,787.90 \pm 97.70 \mathrm{c}$ & $1,475.43 \pm 16.55 \mathrm{c}$ & $66.61 \pm 1.02 \mathrm{c}$ & $7,424.24 \pm 251.65 \mathrm{c}$ \\
\hline
\end{tabular}

${ }^{\mathrm{z}}$ The number of days after fumigation starts the day when the plastic film was opened. Note that $52 \mathrm{~d}, 112 \mathrm{~d}$, and $172 \mathrm{~d}$ refer to $52 \mathrm{~d}, 105 \mathrm{~d}$, and $172 \mathrm{~d}$, respectively, since the opening of the plastic film, which corresponds to $45 \mathrm{~d}, 105 \mathrm{~d}$, and $165 \mathrm{~d}$, respectively, after Malus hupehensis Rehd. seedlings were planted.

${ }^{\mathrm{y}}$ Data are mean \pm SE $(\mathrm{n}=3)$.

${ }^{\mathrm{x}}$ Values in the same column marked with the same letter are not significantly different at $P<0.05$ according to Duncan's new multiple range test.

$\mathrm{CK}=$ control check; $\mathrm{T} 1$ = metham sodium; $\mathrm{T} 2$ = dazomet; $\mathrm{T} 3$ = calcium cyanamide; $\mathrm{T} 4$ = 1,3-dichloropropene; $\mathrm{T} 5=$ methyl bromide .

materials in soil, energy metabolism, and soil quality (Shao et al., 2015). Du et al. (2017) found that soil enzyme activity was altered to different degrees after fumigants were applied, and different fumigants had different effects on soil enzyme activity. Nannipieri et al. (2012) reported that soil fumigation led to a decline in soil microbial activity, which resulted in a decrease in soil enzyme activity. However, soil enzyme activity recovered gradually with time. In our study, T1, T2, $\mathrm{T} 3, \mathrm{~T} 4$, and $\mathrm{T} 5$ reduced significantly replanted soil urease, sucrase, phosphatase, and catalase activity; but, as time progressed, the magnitude of the increases differed. This pattern may stem from the fact that fumigation can kill soil microorganisms to some extent, but as the beneficial microbes recover, so does the enzyme activity. Among treatments, the slowest recovery was observed for
T5, followed by $\mathrm{T} 1, \mathrm{~T} 2, \mathrm{~T} 4$, and $\mathrm{T} 3$. The strength of the fumigant affected microbial recovery and thus enzyme activity. However, after the application of calcium cyanamide (T3), the lack of a significant difference in urease activity among the treatments and the control may stem from the fact that calcium cyanamide contains large amounts of nitrogen. Indeed, studies have found that applying nitrogen fertilizer not only provides the soil urease required for enzymatic reactions and enhances soil urease activity, but also improves nitrogen nutrition for soil microbial growth and thus contributes to the production of urease.

\section{Number of microorganisms and the gene copies of Fusarium oxysporum}

The transformation of substances in soil is related closely to microorganisms, and the structure of the soil microbial community can reflect the quality of soil to a certain extent (Su et al., 2020). Long-term replanting leads to imbalances in soil microbial community structure, increases in pathogenic bacteria, and the transformation of soil microorganisms from bacteria dominant to fungus dominant (Braun et al., 2010). Several studies have indicated that Fusarium, Columbaria, Saproterus, and Trichinella are the main causes of successive cropping obstacles in apple-producing areas in the United States and Italy (Manici et al., 2003; Schoor et al., 2009). The main pathogens of ARD in the Bohai Gulf region and the Loess Plateau region of northwest China are Fusarium fungi, which are highly pathogenic to apple rootstock M. hupehensis Rehd. seedlings (Wang et al., 2018). Previous studies have found that fumigants such as methyl bromide 
and bitter chloride have significant inhibitory effects on Fusarium oxysporum (Dangi et al., 2015). Our study assessed the effects of five types of fumigant (metham-sodium, dazomet, 1,3-dichloropropene, calcium cyanamide, and methyl bromide) on replanted soil by measuring the number of soil bacteria, fungi, and Fusarium oxysporum. The five fumigants reduced significantly the number of soil bacteria, fungi, and gene copy number of Fusarium oxysporum. This finding may stem from the fact that different soil fumigants tend to kill replanted soil microorgan-

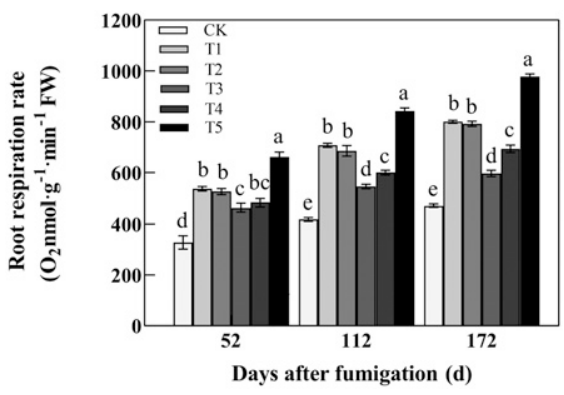

Fig. 4. Effects of different fumigant treatments on the root respiration rate of Malus hupehensis Rehd. The number of days after fumigation starts the day when the plastic film was opened. Note that $52 \mathrm{~d}, 112 \mathrm{~d}$, and $172 \mathrm{~d}$ refer to $52 \mathrm{~d}$, $112 \mathrm{~d}$, and $172 \mathrm{~d}$, respectively, since the opening of the plastic film, which corresponds to 45 d, 105 d, and 165 d, respectively, after Malus hupehensis Rehd. seedlings were planted. Data are mean $\pm \operatorname{SE}(n=3)$. Values marked with the same letter within a sampling event are not significantly different at $P<0.05$ according to Duncan's new multiple range test. $\mathrm{O}_{2}$, oxygen; CK, control check; T1, metham sodium; T2, dazomet; T3, calcium cyanamide; T4, 1,3dichloropropene; T5, methyl bromide. isms, which is consistent with the findings of Kim et al. (2020). Among these fumigants, the greatest reductions were induced by methyl bromide, metham-sodium, and dazomet, followed by 1,3-dichloropropene and calcium cyanamide. The number of bacteria, fungi, and the copy number of Fusarium oxysporum genes in each treatment recovered gradually with time. The efficacy of fumigant might reduce gradually, and the structure of the soil microbial community might recover gradually; however, the recovery time and recovery effect require further study.

\section{Plant morphological properties}

After long-term replanting, the increase in soil pathogenic microorganisms, the accumulation of allelochemicals, and the imbalance of nutrients are all adverse factors restricting the growth of $M$. hupehensis Rehd. seedlings. Under these adverse conditions, the growth of plant roots is inhibited. As the center of metabolism of the underground part of plants, plant roots promote the growth of the aboveground part through the absorption of water and mineral elements (Suchoff et al., 2018). Wang et al. (2019) found that ARD inhibited root growth significantly, leading to significantly lower root length, root area, and root tip number relative to normal plants. However, all five fumigants in our study promoted the growth and root respiration rate of $M$. hupehensis seedlings. Thus, the five fumigants might have alleviated the adverse conditions of replanted soil, promoted the growth of plant roots, and improved aboveground growth. Methyl bromide was the most effective fumigant, followed by metamsodium, dazomet, 1,3-dichloropropene, and calcium cyanamide.

\section{$\mathrm{NH}_{4}{ }^{+}-\mathrm{N}$ and $\mathrm{NO}_{3}{ }^{-}-\mathrm{N}$ content in soil}

All types of mineral elements affect the growth of the root system (Miller et al., 2013). For example, the level of nitrogen is one of the most important factors affecting plant growth and development (Djidonou et al., 2019). Ayankojo et al. (2020) showed that $\mathrm{NH}_{4}{ }^{+}-\mathrm{N}$ and $\mathrm{NO}_{3}{ }^{-}-\mathrm{N}$ are the main forms of nitrogen taken up by plant roots. As these forms of nitrogen can be transformed by nitrification and denitrification, nitrification is one of the most important processes in the process of soil nitrogen transformation. Apples are generally thought to be $\mathrm{NO}_{3}{ }^{-} \mathrm{N}$ plants, and the nitrogen uptake of both spring and summer plants is greater than that of $\mathrm{NH}_{4}{ }^{+}-\mathrm{N}$ (Gu et al., 1987). In our experiment, we found that the content of $\mathrm{NH}_{4}{ }^{+}-\mathrm{N}$ in the soil was increased after the fumigation treatment, whereas the content of $\mathrm{NO}_{3}^{-}-\mathrm{N}$ was decreased. This pattern might be explained by the fact that dead soil microorganisms decompose to produce a large amount of $\mathrm{NH}_{4}{ }^{+}-\mathrm{N}$ after fumigation (Yamamoto et al., 2008). In addition, soil fumigation might also depress microbiological nitrification and affect the conversion of $\mathrm{NH}_{4}{ }^{+}-\mathrm{N}$ to $\mathrm{NO}_{3}{ }^{-}-\mathrm{N}$, thus leading to the accumulation of $\mathrm{NH}_{4}{ }^{+}-\mathrm{N}$ and decreases in $\mathrm{NO}_{3}{ }^{-} \mathrm{N}$ (Yan et al., 2015). The contents of $\mathrm{NH}_{4}{ }^{+}-\mathrm{N}$ and $\mathrm{NO}_{3}{ }^{-}-\mathrm{N}$ in each treatment generally showed a decreasing trend over time, which may stem from the fact that M. hupehensis Rehd. enters a flourishing growth period and its absorption capacity increases gradually. As a consequence, the contents of $\mathrm{NH}_{4}{ }^{+}-\mathrm{N}$ and $\mathrm{NO}_{3}{ }^{-}-\mathrm{N}$ in the soil decrease; however, in our study, the concentrations of $\mathrm{NH}_{4}{ }^{+}-\mathrm{N}$ and $\mathrm{NO}_{3}{ }^{-}-\mathrm{N}$ were always greater in the treatments than in the control.

The Growth of Malus hupehensis Rehd. seedlings at 172 Days after Fumigation

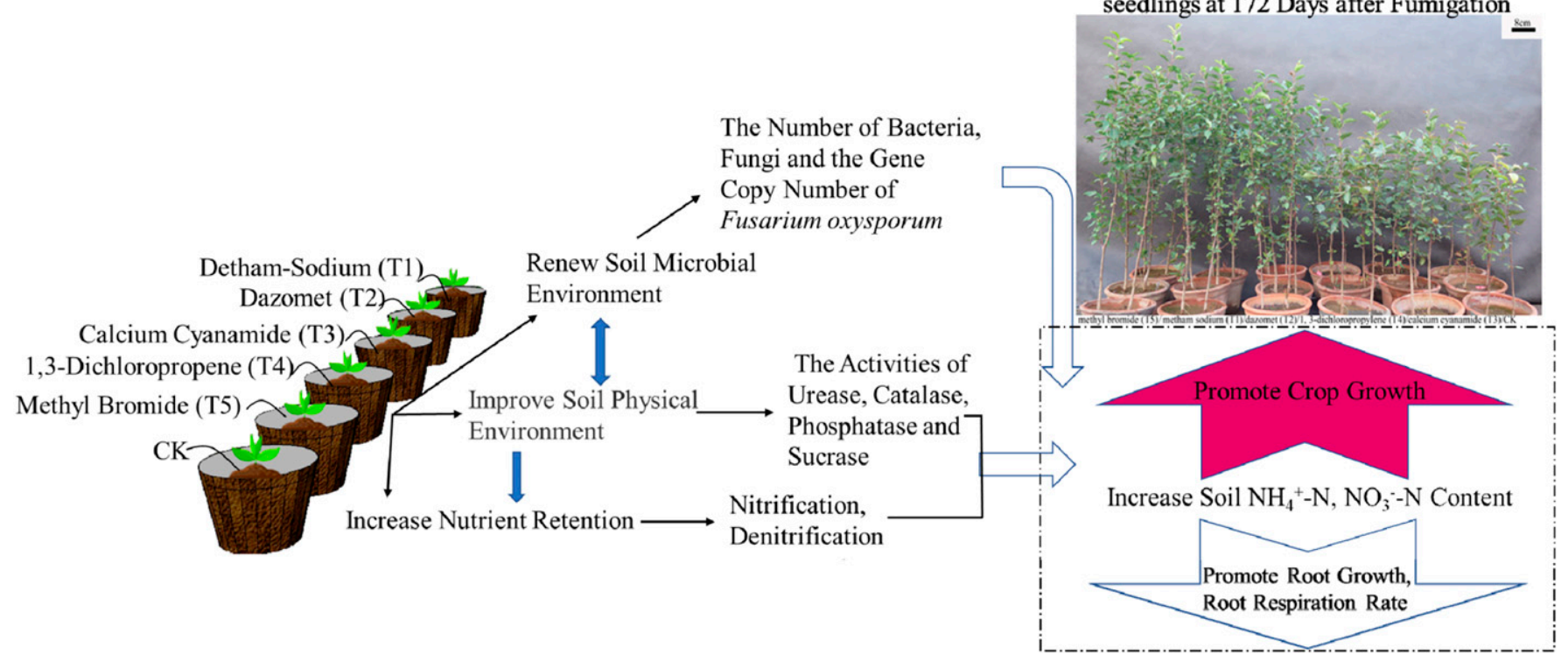

Fig. 5. Conceptual diagram depicting the effects of fumigants on the internal environment of the replanted soil of apple trees and the growth status of Malus hupehensis Rehd. seedlings $172 \mathrm{~d}$ after fumigation. $\mathrm{NH}_{4}{ }^{+}-\mathrm{N}$, ammonium nitrogen; $\mathrm{NO}_{3}{ }^{-} \mathrm{N}$, nitrate nitrogen; $\mathrm{CK}$, control check; $\mathrm{T} 1$, metham sodium; $\mathrm{T} 2$, dazomet; T3, calcium cyanamide; T4, 1,3-dichloropropene; T5, methyl bromide. 


\section{Conclusions}

We used five fumigants to treat the replanted soil of apple trees and investigated the effects of fumigants on the soil environment and the growth characteristics of M. hupehensis Rehd. seedlings. The results indicate that dazomet and metham-sodium had clear effects on the growth of $M$. hupehensis Rehd. and the soil environment, in addition to the banned fumigant methyl bromide. Furthermore, dazomet is more convenient to transport than metham-sodium, and metham-sodium is far cheaper than dazomet (Fig. 5). Thus, we recommend that metham-sodium or dazomet be used as needed to maximize production. In general, our experimental results provide guiding information that could be used to aid in the selection of suitable fumigants to treat the replanted soil of apple trees and thus control ARD. These findings also show promise in helping to promote the development of the apple industry.

\section{Literature Cited}

Ayankojo, I.T., K.T. Morgan, D.M. Kadyampakeni, and G.D. Liu. 2020. 'Tomato growth, yield, and root development, soil nitrogen and water distribution as affected by nitrogen and irrigation rates on a Florida sandy soil. HortScience 55:1744-1755, doi: 10.21273/HORTSCI1517720.

Bangarwa, S.K., J.K. Norsworthy, and E.E. Gbur. 2009. Covercrop and herbicide combinations for weed control in polyethylene-mulched bell pepper. HortTechnology 19:405-410, doi: 10.1007/s10658-008-9382-2.

Bletsos, F.A. 2010. Use of grafting and calcium cyanamide as alternatives to methyl bromide soil fumigation and their effects on growth, yield, quality and fusarium wilt control in melon. J. Phytopathol. 153(3):155-161, doi: 10.1111/j.1439-0434.2005.00945.x.

Braun, P., K.D. Fuller, K. McRae, and S.E. Fillmore. 2010. Response of 'Honeycrisp ${ }^{\circledR}$ ', apple trees to combinations of pre-plant fumigation, deep ripping, and hog manure compost incorporation in a soil with replant disease. HortScience 45:1702-1707, doi: 10.1002/ mde. 2688

Chen, H.J., J.M. Zhao, J. Jiang, S.M. Chen, Z.Y. Guan, F.D. Chen, W.M. Fang, and S. Zhao. 2019. Assessing the influence of fumigation and Bacillus subtilis-based biofungicide on the microbiome of chrysanthemum rhizosphere. Agriculture 9(12):255, doi: 10.3390/agriculture 9120255.

Dangi, S.R., J.S. Gerik, T. Rebecca, and H. Ajwa. 2015. Soil microbial community structure and target organisms under different fumigation treatments. Appl. Environ. Soil Sci. 2015:173180, doi: 10.1155/2015/673264.

Djidonou, D., X. Zhao, K.E. Koch, and L. Zotarelli. 2019. Nitrogen accumulation and root distribution of grafted tomato plants as affected by nitrogen fertilization. HortScience 54:19071914, doi: 10.21273/HORTSCI14066-19.

Du, L., B. Huang, N. Du, S. Guo, S. Shu, and J. Sun. 2017. Effects of garlic/cucumber relay intercropping on soil enzyme activities and the microbial environment in continuous cropping. HortScience 52:78-84, doi: 10.21273/HORTSCI 11442-16.

Fan, B.G., C.H. Li, H.M. Wang, and H.B. Ding. 2016. Experimental study on lime nitrogen disinfection and bioremediation technology of Agaricus japonicus in strawberry greenhouse. Agr. Eng. Technol. 36(20):15-16, doi: 10.16815/ j.cnki.11-5436/s.2016.20.008.

Frank, Z.R., Y. Ben-Yephet, and J. Katan. 1986. Synergistic effect of metham and solarization in controlling delimited shell spots of peanut pods. Crop Prot. 5(3):199-202, doi: 10.1016/ 0261-2194(86)90102-X.

Gu, M.R., H.R. Shu, and H.W. Zhou. 1987. A study on the nitrogen nutrition of apple trees: V. The characteristics of absorption and transportation for various of $15 \mathrm{~N}$ fertilizers. J. Shandong Agr. Univ. 18(4):17-24.

Hoffmann, M., H.A. Ajwa, B.B. Westerdahl, S.T. Koike, M. Stanghellini, C. Wilen, and S.A. Fennimore. 2020. Multitactic preplant soil fumigation with allyl isothiocyanate in cut flowers and strawberry. HortTechnology 30:251-258, doi: 10.21273/HORTTECH 04362-19.

Hwang, S.F., H.U. Ahmed, S.E. Strelkov, Q. Zhou, B.D. Gossen, and G. Peng. 2017. Effects of rate and application method on the efficacy of metam sodium to reduce clubroot (Plasmodiophora brassicae) of canola. Eur. J. Plant Pathol., doi: 10.1007/s10658-017-1281-y.

Ibekwe, A.M. 2004. Effects of fumigants on non-target organisms in soils. Adv. Agron. 83(04):1-35, doi: 10.1016/S0065-2113(04)83001-3.

Kim, D., M. Hoffmann, S. Kim, B.A. Scholler, and S.A. Fennimore. 2020. Integration of steam with allyl-isothiocyanate for soil disinfestation. HortScience 55:920-925, doi: 10.21273/ HORTSCI14600-20.

Li, J., B. Huang, Q. Wang, Y. Li, W. Fang, and D. Han. 2016. Effects of fumigation with metamsodium on soil microbial biomass, respiration, nitrogen transformation, bacterial community diversity and genes encoding key enzymes involved in nitrogen cycling. Sci. Total Environ. 598:1027-1036, doi: 10.1016/j.scitotenv.2017.02. 058.

Manici, L.M., C. Ciavatta, M. Kelderer, and G. Erschbaumer. 2003. Replant problems in South Tyrol: Role of fungal pathogens and microbial population in conventional and organic apple orchards. Plant Soil 256(2):315-324, doi: 10.1023/A:1026103001592.

Mao, L., Q. Wang, D. Yan, T. Ma, P. Liu, J. Shen, Y. Li, C. Ouyang, M. Guo, and A. Cao. 2014. Evaluation of chloropicrin as a soil fumigant against Ralstonia solanacarum in ginger (Zingiber officinale Rosc.) production in China. PLoS One 9:e91767, doi: 10.1371/journal.pone. 0091767.

Meng, T., G. Ren, G. Wang, and Y. Ma. 2019. Impacts on soil microbial characteristics and their restorability with different soil disinfestation approaches in intensively cropped greenhouse soils. Appl. Microbiol. Biotechnol. 103(2), doi: 10.1007/s00253-019-09964-z.

Miller, G., A. Khalilian, J.W. Adelberg, H.J. Farahani, and C.E. Wells. 2013. Grafted watermelon root length density and distribution under different soil moisture treatments. HortScience 48:1021-1026, doi: 10.21273/HORTSCI. 48.8.1021.

Nannipieri, P., L. Giagnoni, G. Renella, E. Puglisi, B. Ceccanti, and G. Masciandaro. 2012. Soil enzymology: Classical and molecular approaches. Biol. Fertil. Soils 48(7):743-762, doi: 10.1007/s00374-012-0723-0.

Nicola, L., E. Turco, D. Albanese, C. Donati, M. Thalheimer, and M. Pindo. 2017. Fumigation with dazomet modifies soil microbiota in apple orchards affected by replant disease. Appl. Soil
Ecol. 113:71-79, doi: 10.1016/j.apsoil.2017. 02.002 .

Pinkerton, J.N., K.L. Ivors, M.L. Miller, and L.W Moore. 2000. Effect of soil solarization and cover crops on populations of selected soilborne plant pathogens in western Oregon. Plant Dis. 84(9):952-960, doi: 10.1094/PDIS.2000. 84.9.952.

Qiao, K., S. Dong, H. Wang, X. Xia, X. Ji, and K. Wang. 2012. Effectiveness of 1,3-dichloropropene as an alternative to methyl bromide in rotations of tomato (Solanum lycopersicum) and cucumber (Cucumis sativus) in China. Crop Prot. 38:30-34, doi: 10.1016/j.cropro.2012.03. 007.

Qiao, K., L. Jiang, H. Wang, X. Ji, and K. Wang. 2010. Evaluation of 1,3-dichloropropene as a methyl bromide alternative in tomato crops in China. J. Agr. Food Chem. 58(21):1139511399, doi: 10.1021/jf102830y.

Ren, Z., Y. Li, W. Fang, D. Yan, and A. Cao. 2018. Evaluation of allyl isothiocyanate as a soil fumigant against soil-borne diseases in commercial tomato (Lycopersicum esculentum Mill.) production in china. Pest Mgt. Sci. 74(9): doi: 10.1002/ps.4911.

Schoor, L.V., S. Denman, and N.C. Cook. 2009. Characterisation of apple replant disease under South African conditions and potential biological management strategies. Scientia Hort. 119:153-162, doi: 10.1016/j.scienta.2008.07. 032.

Shao, X.X., W.Y. Yang, and M. Wu. 2015. Seasonal dynamics of soil labile organic carbon and enzyme activities in relation to vegetation types in Hangzhou Bay tidal flat wetland. PLoS One, doi: 10.1371/journal.pone.0142677.

Sheng, Y., H. Wang, M. Wang, H. Li, and Z. Mao. 2020. Effects of soil texture on the growth of young apple trees and soil microbial community structure under replanted conditions. Hort. Plant J. 6(3), doi: 10.1016/j.hpj.2020. 04.003.

Ślusarski, C. and S.J. Pietr. 2009. Combined application of dazomet and Trichoderma asperellum as an efficient alternative to methyl bromide in controlling the soil-borne disease complex of bell pepper. Crop Prot. 28(8):668 674, doi: 10.1016/j.cropro.2009.03.016.

Su, H., H. Zhang, C. Wang, J. Huang, J. Shang, N. Zhang, D. Wang, and K. Li. 2020. Grape pruning material improves root development and soil microecology in 'Shine Muscat' grape soils. HortScience 55:2011-2022, doi: 10.21273/ HORTSCI15400-20.

Suchoff, D.H., C.C. Gunter, J.R. Schultheis, M.D. Kleinhenz, and F.J. Louws. 2018. A rootstock effect on grafted tomato transplant shoot and root responses to drying soils. HortScience 53:1586-1592, doi: 10.21273/HORTSCI1321518

Wang, G.S., Z.Q. Ma, F.B. Pan, C.P. Tian, J. Chen, and J.Z. Wang. 2019. Effects of replant on nitrogen uptake, distribution and utilization of soil microorganisms and Malus hupehensis Rehd seedlings. J. Plant Nutrition and Fertilizer 25(03):481-488. (in Chinese).

Wang, Y., F. Pan, G. Wang, G. Zhang, Y. Wang, and X. Chen. 2014. Effects of biochar on photosynthesis and antioxidative system of Malus hupehensis Rehd. seedlings under replant conditions. Scientia Hort. 175:9-15, doi: 10.1016/j.scienta.2014.05.029

Wang, G.S., C.M. Yin, F.B. Pan, X.B. Wang, L. Xiang, Y.F. Wang, J.Z. Wang, C.P. Tian, J. Chen, and Z.Q. Mao. 2018. Analysis of the fungal community in apple replanted soil 
around Bohai Gulf. Hort. Plant J. 4(05):175181, doi: CNKI:SUN:YYZW.0.2018-05-001.

Xue, X., W. Mai, Z. Zhao, K. Zhang, and C. Tian. 2017. Optimized nitrogen fertilizer application enhances absorption of soil nitrogen and yield of castor with drip irrigation under mulch film. Ind. Crops Prod. 95:156-162, doi: 10.1016/ j.indcrop.2016.09.049.

Yamamoto, T., V.U. Ultra, Jr., S. Tanaka, K. Sakurai, and K. Iwasaki. 2008. Effects of methyl bromide fumigation, chloropicrin fumigation and steam sterilization on soil nitrogen dynamics and microbial properties in a pot culture experiment. Soil Sci. Plant Nutr.
54:886-894, doi: 10.1111/j.1747-0765.2008. 00319.x.

Yan, D.D., Q.X. Wang, Y. Li, C.B. Ouyang, M.X. Guo, B. John, N.S. Jong, Y.Y. Alisa, H. Phil, W. Don, and A.C. Cao. 2017. Gelatin encapsulation of chloropicrin and 1,3-dichloropropene as fumigants for soilborne diseases in the greenhouse cultivation of cucumber and tomato. J. Integr. Agr. 16(08):1758-1766, doi: 10.1016/S2095-3119(16)61623-4.

Yan, D., Q. Wang, L. Mao, T. Ma, Y. Li, C. Ouyang, M. Guo, and A. Cao. 2015. Interaction between nitrification, denitrification and nitrous oxide production in fumigated soils.
Atmos. Environ. 103:82-86, doi: 10.1016/ j.atmosenv.2014.09.079.

Yellareddygari, S.K.R. and N.C. Gudmestad. 2018.

Effect of soil temperature, injection depth, and rate of metam sodium efficacy in fine-textured soils with high organic matter on the management of verticillium wilt of potato. Amer. J. Potato Res., doi: 10.1007/s12230-018-9641-5.

Yim, B., K. Smalla, and T. Winkelmann. 2013. Evaluation of apple replant problems based on different soil disinfection treatments: Links to soil microbial community structure? Plant Soil, doi: 10.1007/s11104-016-2876-3. 